Tomasz Róg

Państwowa Wyższa Szkoła Zawodowa w Pile

tomaszrog@yahoo.co.uk

\title{
GLOTTODYDAKTYCZNE OBSZARY BADAŃ NAD KOMPETENCJĄ MIĘDZYKULTUROWA
}

\section{Glottodidactic areas of research on intercultural competence}

As globalisation promotes cross-cultural approaches to foreign language education, the article scrutinises research on intercultural competence conducted in the field of glottodidactics. It aims at offering a possibly most comprehensive outline of our state-of-the-art knowledge of interculturality in teaching foreign languages. The following parts of the present article will look at pre- and in-service teachers, teaching materials, lesson planning, new technologies, and the age of learners, all with a view to indicating the achievements and challenges of teaching intercultural competence as an element of foreign language education.

Keywords: intercultural competence, interculturality, glottodidactics

Słowa kluczowe: kompetencja interkulturowa, interkulturowość, glottodydaktyka

\section{Wstęp}

Problematyka międzykulturowości stanowi dla polskiej glottodydaktyki obszar poszukiwań od blisko dwudziestu lat. W tym czasie pojawiły się, współistniały, a nawet konkurowały ze sobą różne podejścia do badań nad zjawiskami komunikacji międzykulturowej w odniesieniu do dydaktyki języka obcego. Dość długi jak na młodą dyscyplinę, jaką jest glottodydaktyka, okres badań skłania do pewnych podsumowań na tym polu. Poniższy artykuł ma zatem charakter porządkujący w odniesieniu do obszarów polskich badań glottodydaktycznych 
nad kompetencją międzykulturową. Jego nadrzędnym celem jest przeanalizowanie stanu badań, wskazanie punktów styczności i sprzeczności w ich wynikach oraz zasygnalizowanie potencjalnych ścieżek dalszego rozwoju badań nad kompetencją międzykulturową.

W dalszej części artykułu przyjrzymy się szczegółowo głównym obszarom poszukiwań badaczy międzykulturowości w dydaktyce języków obcych. Przegląd literatury objął repozytoria prac naukowych (m.in. AMUR, DBC, UW, UŁ), czasopisma (przede wszystkim „Neofilolog”, "Lingwistyka Stosowana” i „Języki Obce w Szkole”), serie wydawnicze (głównie „Język a komunikacja” wydawnictwa Tertium) oraz prace zbiorowe i monografie poświęcone tematyce kompetencji międzykulturowej w zakresie glottodydaktyki i dydaktyki języków obcych. Poszukiwanymi słowami kluczowymi były: kompetencja/komunikacja interkulturowa/międzykulturowa, kultura, edukacja kulturowa itp. (również w języku angielskim). W ten sposób autor dotarł do 107 opracowań, z czego większość (56\%) stanowiła prace przekrojowe, analityczne lub o charakterze postulatywnym (60), a pozostałe były sprawozdaniami z przeprowadzonych badań (47). Najstarsze publikacje naukowe pochodzą z 2002 roku (3 publikacje), najnowsze z 2015 roku (7 publikacji), zaś większość przypada na lata 2010-2014 (60 publikacji).

Zainteresowanie glottodydaktyki problematyką komunikacji międzykulturowej ma dwa źródła. Pierwsze z nich jest związane z kluczowym dla glottodydaktyki zjawiskiem osiągania przez ucznia kompetencji komunikacyjnej, a drugie - z wyzwaniem holistycznego rozwoju ucznia, co stanowi cel edukacji w ogóle. Jeśli chodzi o kompetencję komunikacyjną w języku obcym, która jest uznawana za cel wszelkich działań glottodydaktycznych (Wilczyńska i Michońska-Stadnik, 2010: 50), jej uszczegółowienie w postaci międzykulturowej/interkulturowej kompetencji komunikacyjnej (Byram, 1997) wynika z ograniczeń pierwotnie rozumianej kompetencji komunikacyjnej, tj. postrzegania jej jako równej kompetencji rodzimego użytkownika języka (zob. Siek-Piskozub, 2012a: 96). Trudności wynikające z komunikacji międzykulturowej zmusiły badaczy do zrewidowania takiego stanowiska i skierowania procesów badawczych w obrębie glottodydaktyki na zjawiska związane z nabywaniem kompetencji komunikacyjnej z uwzględnieniem kwestii kulturowych.

Drugim powodem zainteresowania międzykulturowością w nauczaniu języka obcego jest wspomniany wyżej holistyczny rozwój ucznia, stanowiący nadrzędny cel wszelkich działań edukacyjnych. Rozwijanie międzykulturowej kompetencji komunikacyjnej jest przykładem takiego właśnie nauczania, które uczy otwartości, tolerancji, kreatywności i umiejętnego wyrażania własnych myśli. Osoba, która posiadła międzykulturową kompetencję komunikacyjną w języku obcym, jest lepiej przygotowana do komunikacji niż rodzimy użytkownik, który jest jej pozbawiony. 


\section{Nauczyciele języków obcych wobec rozwijania kompetencji międzykulturowej}

Jednym z najczęściej eksplorowanych pól badawczych w obrębie kompetencji międzykulturowej jest edukacja nauczycieli, a w szczególności stopień ich przygotowania do pełnienia roli mediatorów interkulturowych. Nauczanie języka obcego uznawane jest za tożsame z nauczaniem kultury użytkowników tego języka, a zatem postuluje się, że aby uczynić międzykulturową kompetencję komunikacyjną celem działań nauczycielskich, nauczyciele sami muszą wejść w rolę mediatorów kulturowych (Bandura, 2007: 64-65; Mackiewicz, 2009: 72; Zając, 2012: 15; Siek-Piskozub, 2014a: 192) ${ }^{1}$.

Nauczyciel jako mediator interkulturowy to nie tylko osoba przekazująca wiedzę na temat języka i kultury, ale stale kształcący się animator uświadamiający uczniom, od czego zależy ich postrzeganie drugiego człowieka i w jaki sposób kontakty z innymi kulturami pozwalają im dowiedzieć się więcej nie tylko o Innym, ale także o sobie samym. W programach nauczania podkreśla się także wagę przekazywania uczniom umiejętności wglądu we własną kulturę, odnajdywania własnej tożsamości, ciekawości wobec innych (Kaiser i Kuciński, 2002: 6), nabrania dystansu do operowania stereotypami (Podkowińska-Lisowicz, 2004: 11) oraz umiejętności rozpoznawania znaczeń metaforycznych, aluzji, symboli kulturowych, które mogą powodować niejednoznaczność (Dmowska, 2005: 144).

Badania dotyczące przygotowania nauczycieli do pełnienia roli mediatorów kulturowych (np. Kuriata, 2002; Strzałka, 2005; Aleksandrowicz-Pędich, 2007; Bandura, 2007; Utri, 2007; Białek, 2009; Mihułka, 2012; Chudak, 2013) pokazują jednak, że nauczyciele języków obcych nie są przygotowani do jej pełnienia, nie wiedzą też do końca, w jaki sposób edukacja międzykulturowa miałaby wyglądać. Przykładowo Białek (2009) wykazała, że choć znacząca większość nauczycieli uznaje się za gotowych do pełnienia roli pośredników między kulturami, to w istocie nie wiedzą oni, jak wdrażać podejście międzykulturowe. Co więcej przyznają (Białek, 2009: 245), że klasa językowa nie jest najlepszym miejscem na tego typu edukację i uznają, że komunikacja międzykulturowa powinna stanowić osobny przedmiot w programie nauczania.

Badani nauczyciele często zwracają również uwagę (Bandura, 2007; Białek, 2009) na odczuwalny dyskomfort w związku z tym, że nie są natywnymi mówcami danego języka. W powszechnym przekonaniu (nie tylko nauczycieli,

\footnotetext{
${ }^{1} \mathrm{~W}$ polskiej literaturze glottodydaktycznej używa się również określeń intercultural speaker (Karpińska-Musiał, 2006), pośrednik kulturowy (Zawadzka, 2004; Aleksandrowicz-Pędich, 2005) i nauczyciel kompetentny interkulturowo (Strzałka, 2005).
} 
ale zwłaszcza uczniów) natywny użytkownik jest lepszym nauczycielem. W konsekwencji nauczanie o kulturze nie stanowi istotnego elementu na lekcjach języka obcego, choć, jak pokazują badania Strzałki (2005: 375), uczniowie oczekują takich elementów. Rozwijanie u uczniów kompetencji międzykulturowej jest zatem działaniem zazwyczaj przypadkowym i marginalnym, mimo że nauczyciele przypisują jej w badaniach istotne znaczenie (patrz: Wilczyńska, 2002: 128).

W świetle prowadzonych badań pojawia się obraz nauczyciela, który w niewystarczającym zakresie wdraża tematy kulturowe i opiera się głównie na podręczniku (Zagdańska-Dudek, 2012:105), prowadzi sprawne lekcje, ale zdominowane przez nauczanie gramatyki, leksyki lub czterech sprawności językowych (Sobkowiak, 2012:118), zaniedbując elementy społecznokulturowe (Chłopek, 2009a: 66). Okazuje się także, że nauczyciele języków obcych ulegają stereotypom kulturowym $w$ taki sam sposób, jak ich uczniowie, i to mimo kontaktu z kulturami nauczanych języków (Pytlarz, 2005: 217), a treści międzykulturowe są wprowadzane w sposób przypadkowy i zwykle bez świadomości wagi takiej edukacji (Mihułka, 2010: 360). Ponadto, treści te to głównie suche fakty realioznawcze, a nauczyciele zwracają niewielką uwagę na literaturę, sztukę i tematy wymagające autorefleksji, takie jak stereotypy czy komunikacja niewerbalna (Mihułka, 2012: 344).

Jeszcze bardziej niepokojące wnioski wysuwa Sobkowiak (2012: 125), który po analizie lekcji języka obcego stwierdza, że „kształcenie kulturowe odbywa się w polskiej szkole rzadko, a interkulturowość w zasadzie nie istnieje". Jedną z przyczyn tego stanu rzeczy może być "trywializacja” (Mihułka, 2012: 352) pojęcia kultury na filologiach, oznaczająca zredukowanie go do rytuałów związanych z życiem codziennym, a więc oferowanie przyszłym filologom treści kulturoznawczych podobnych do tych, które oferuje się na kursach językowych "mało doświadczonym gastarbeiterom" (Watrowski, 2002: 50 za Mihułka, 2012: 352). Z drugiej strony już samo zdefiniowanie pojęcia „kultura docelowa" nastręcza wielu trudności, stąd proponuje się (Chudak, 2013: 221) rozwijanie takich umiejętności, które pozwolą absolwentom filologii na samodzielne poszerzenie swoich kompetencji w przyszłości. Niestety nie doprecyzowano, jakie to miałyby być umiejętności.

\section{Kształcenie przyszłych nauczycieli - mediatorów kulturowych}

Zainteresowanie badaczy edukacją nauczycieli języków obcych jest związane z uznaniem, że samo omawianie aspektów kulturowych na zajęciach, np. kulturo- czy realioznawstwa, nie jest wystarczające i nie rozwinie kompetencji międzykulturowej przyszłych nauczycieli (Owczarek, 2010: 304). Wobec tego w kształceniu nauczycieli postuluje się obecnie (Chłopek, 2009b: 173; Romanowski, 
2011; Sobkowiak, 2012: 124; Róg, 2013: 267) wprowadzenie treningu kompetencji interkulturowych, który by rozwijał i pogłębiał umiejętności nauczyciela do przyjęcia roli mediatora kulturowego. Jak jednak słusznie zauważa Siek-Piskozub (2014a: 192), choć można uznać, że kompetencja międzykulturowa rozwinie się w wyniku takiego treningu, brak jest zgodności co do tego, jakie powinny być cele takiej edukacji.

Jeszcze przed dziesięcioma laty badane systemy kształcenia nauczycieli języków obcych w Polsce i Europie nie uwzględniały treningów międzykulturowych. Jak wykazywała Aleksandrowicz-Pędich (2005b: 348), badani przez nią nauczyciele nigdy w swojej edukacji nauczycielskiej nie doświadczyli edukacji interkulturowej za wyjątkiem elementów kulturowych pojawiających się w ramach zajęć z kulturoznawstwa. Świadomość międzykulturowa rozwijała się w niezaplanowany sposób w wyniku kontaktu studentów z wykładowcami-cudzoziemcami. Warto także zwrócić uwagę, że w grupie badanej przez cytowaną autorkę znajdowali się zarówno nauczyciele kształceni w latach 70. XX w., jak i ci kształceni po 2000 roku. W odniesieniu do przyszłych nauczycieli języka niemieckiego podkreślano także ograniczone możliwości przeniesienia teorii nauczania w duchu interkulturowości na praktykę dydaktyczną (Adamczak-Krysztofowicz, 2006: 31).

Współcześnie, pomimo jeszcze większej świadomości osób odpowiedzialnych za edukację przyszłych nauczycieli i pomimo często eksplicytnego rozwijania ich postaw interkulturowych (Siek-Piskozub, 2014b:196), osoby kończące studia nauczycielskie przejawiają bardzo zróżnicowane stopnie kompetencji międzykulturowej (Owczarek, 2010; Siek-Piskozub, 2012b), a w testach samooceny często przeceniają jej poziom (Róg, 2013). Wśród badaczy tematu pojawiają się także jeszcze smutniejsze wnioski. Mihułka (2012: 351) uważa, że przyszli nauczyciele języków obcych nie reprezentują nawet postaw neutralnych co do obcej kultury, nie mówiąc już o postawach pozytywnych. Ich myślenie nacechowane jest etnocentryzmem, lękiem przed tym, co obce i stereotypami.

W związku z powyższym glottodydaktycy pracujący z przyszłymi nauczycielami oprócz wspomnianych treningów interkulturowych sugerują różne podejścia do rozwijania kompetencji międzykulturowej u swoich studentów. Proponuje się m.in. korzystanie z międzynarodowych projektów internetowych (Wach, 2015), analizę materiałów medialnych dostępnych on-line (Wilczyńska, 2013), rozwijanie kompetencji medialnej (Chudak, 2013), analizę literatury pięknej (Chylewska-Tölle, 2010; Wałowski, 2012), seminaria poświęcone kompetencji interkulturowej (Siek-Piskozub, 2013), pracę z filmem (Balcerkiewicz i Kułaczkowska, 2010), podróże studyjne i realizowane w ich ramach projekty badawcze (Adamczak-Krysztofowicz, 2012; Sobek, 2012; Chudak, 2013; Grabowska, 2013; Róg, 2014a) i kształtowanie refleksyjności podczas oceny innych kultur (Mihułka, 2014). 
Większość działań skupia się jednak - i słusznie - na treningach interkulturowych. Przykładowo Strzałka (2005) opisuje program i przebieg opracowanego przez siebie seminarium „Kultura w nauczaniu języka angielskiego”. Podczas tych zajęć studenci dowiadywali się m.in. o zjawisku szoku kulturowego, technikach rozwijania świadomości interkulturowej i sposobach ich testowania. Wyniki ankiety przeprowadzonej przez autorkę po zakończeniu seminarium pokazały, że możliwe jest w krótkim czasie „wprowadzenie zmian w pedagogicznej świadomości kulturowej" badanych (Strzałka, 2005: 378). Oznacza to, że przyszli nauczyciele zaobserwowali związki języka z kulturą, konieczność rozwijania kompetencji interkulturowej u uczniów i wykazali zrozumienie dla wprowadzania elementów kulturowych na lekcji jako jej części integralnej, a nie opcjonalnej.

Efektywność opracowanego przez siebie treningu interkulturowego dla przyszłych nauczycieli języków obcych testował także Romanowski (2011 za Siek-Piskozub, 2012a: 104). W jego wyniku studenci jednej z wyższych szkół zawodowych rozwinęli pozytywne postawy wyrażające się większą wrażliwością na różnice kulturowe, gotowością komunikacyjną i pewnością siebie w sytuacjach komunikacyjnych z obcokrajowcami. Brak jednak badań odnoszących się do trwałości tych postaw ani rzeczywistych efektów treningu w autentycznych sytuacjach komunikacyjnych.

Z kolei o module interkulturowym Europejskich Nauczycielskich Studiów Magisterskich (ang. European Master for European Teacher Training) donosi Niżegorodcew $(2010,2012)$. Jednym z celów projektu EMETT jest kształcenie nauczycieli-mediatorów interkulturowych, a w jego ramach przyszli nauczyciele studiują przez jeden semestr w innym kraju, na jednym z ośmiu uniwersytetów. W przypadku opisywanego projektu brak jest w tym momencie badań opisujących efektywność modułu.

\section{Wyzwania międzykulturowe na lekcji języka obcego}

Mimo bogatej literatury dotyczącej praktycznego zastosowania podejścia interkulturowego, niewiele jest badań zajmujących się perspektywą osób uczących się języków obcych. Badania ankietowe dotyczące świadomości uczniów liceum ogólnokształcącego (Róg, 2010) wykazały np., że uczniowie wyjeżdżający za granicę nie są przygotowani na kontakty interkulturowe i wynikające z nich komplikacje. Uczniowie szkół ponadgimnazjalnych wskazują (Mackiewicz, 2006: 34-36), że w czasie zajęć szkolnych nie mieli okazji właściwego poznania kultury docelowej, a tym bardziej rozwijania kompetencji międzykulturowej.

W glottodydaktyce polonistycznej podejście międzykulturowe pozostaje na poziomie jeszcze bardziej teoretycznym niż w nauczaniu języków obcych. Stankiewicz i Żurek (2011: 189) po analizie materiałów dydaktycznych i 
metod nauczania doszły do wniosku, że dominującą tendencją w nauczaniu polskiej kultury jest podejście faktograficzne. Dzieje się to pomimo specyfiki nauczania języka polskiego jako obcego w Polsce. Otóż studenci zazwyczaj wykazują zainteresowanie kulturą, w której się znaleźli, a ponadto grupy takich studentów zwykle składają się z przedstawicieli różnych kultur, co tym bardziej sprzyja wykorzystywaniu podejścia międzykulturowego. Niestety, podejście to jest realizowane w dość skromnym wymiarze (tamże: 192).

Problemem polskich uczniów i nauczycieli jest niedostateczna umiejętność stosowania reguł pragmatycznych obowiązujących w danym języku. Okazuje się bowiem (Jodłowiec i Urban, 2010: 320), że uczący się, bez względu na poziom zaawansowania, nie różnią się między sobą jeśli chodzi o poziom kompetencji pragmatycznej. Zauważa się także, że interkulturowość na lekcjach jest często bagatelizowana lub stanowi dodatek do innych celów, a materiały dydaktyczne są pozbawione celów afektywnych. Tym samym w szkole jest przekazywana głównie wiedza, a nie jej praktyczne zastosowanie (Żylińska, 2003: 51; Mihułka, 2012: 336-339).

Wśród sposobów kształtowania pozytywnych postaw uczniów wobec przedstawicieli innych kultur wskazuje się m.in.:

- rozpoznawanie symboli kulturowych, analiza zachowań codziennych, stylów komunikowania się w danej kulturze, wartości i postaw (Aleksandrowicz-Pędich, 2005a: 35),

- wykorzystanie technik ludycznych (Jodłowiec, 2005: 272),

- wykład, symulację, odgrywanie ról, dyskusję, obserwacje i spekulacje, analizy procesów komunikacji interkulturowej, strategię loop input (tj. to, co jest nauczane, jest tożsame z tym, jak jest nauczane) (Kurtyka, 2005: 89-90),

- różne formy dyskusji, debat i wywiadów (Matlakiewicz i SolarczykSzewc, 2005: 96),

- test skojarzeń, analizę stereotypów i przysłów, krytyczne spojrzenie na przesądy (Paprocka-Piotrowska, 2007: 287-291),

- zadania pozwalające zrozumieć inność kulturową (Torenc, 2007: 134),

- pracę z filmem o tematyce kulturowej: przed obejrzeniem określenie cech charakterystycznych dla poszczególnych grup narodowościowych, w trakcie oglądania wyodrębnienie głównych wątków, wskazanie osób wzbudzających największą sympatię i antypatię, a w ramach dyskusji odniesienie rzeczywistości filmowej do własnej wiedzy i doświadczeń (Balcerkiewicz i Kułaczkowska, 2010: 182-183),

- $\quad$ identyfikację standardów kulturowych poprzez indukcję i dedukcję, wyszukiwanie językowych „indykatorów” obcych i własnych standardów 
kulturowych, wyszukiwanie poznanych wcześniej standardów kulturowych w materiałach dydaktycznych (Mackiewicz, 2010: 142-144),

- ćwiczenia tłumaczeniowe, analizę zapożyczeń z języków obcych, analizę danych statystycznych dotyczących wybranych aspektów kulturowych, badanie własnego otoczenia pod kątem danego zagadnienia, analizę wymiany międzyszkolnej (Wójcik, 2010: 169-173),

- gry przygotowane na użytek warsztatów międzykulturowych (Stankiewicz i Żurek, 2011: 192),

- wykorzystywanie przede wszystkim materiałów autentycznych, takich jak: obrazki, filmy, teksty literackie i reklamy oraz projekty własne uczniów (Żydek-Bednarczuk, 2012: 28),

- stosowanie wizualizacji (fragmenty programów telewizyjnych, Internet, fotografia, obraz), porównywanie kultur, podkreślanie podobieństw i podejmowanie tematów trudnych, świadome akcentowanie tego, co wartościowe i interesujące $u$ innych, odwoływanie się do emocji uczniów i rozwijanie ich empatii (Karolczuk, 2014: 221-223),

- $\quad$ projekty etnograficzne, studia przypadku, zdarzenia krytyczne, symulacje, dramę, badania terenowe, analizę tekstów kulturowych (Róg, 2014b: 202-214).

Istotne jest także poznanie fundamentalnych wartości, na których opiera się ich kultura oraz kultura drugiej strony (Niżegorodcew, 2015: 28).

\section{Materiały dydaktyczne a rozwijanie kompetencji międzykulturowej}

Ważnym źródłem informacji dotyczących sposobów nauczania kompetencji międzykulturowej w szkole jest analiza materiałów dydaktycznych, a zwłaszcza podręczników, które są główną pomocą nauczyciela. Okazuje się, że podręcznik nierzadko stanowi jedyne źródło odniesień kulturowych (Chłopek, 2009: 65-66; Sobkowiak, 2012: 119). Opinie wśród badaczy są jednak dość podzielone, część zwraca uwagę na brak odpowiedniej liczby i jakości ćwiczeń interkulturowych, część natomiast chwali dostępne na rynku podręczniki za odpowiednie potraktowanie zagadnienia treningu międzykulturowego.

$Z$ jednej strony wskazuje się, że problemem w rozwijaniu kompetencji międzykulturowej jest to, że materiały dydaktyczne, zwłaszcza podręczniki, traktują kulturę obcą marginalnie (Bandura, 2007; Kaszyński, 2009; Krawiec, 2010), a niekiedy wręcz utrwalają stereotypy kulturowe (Piórkowska, 2005; Spychała, 2007). Uważa się także, że na polskim rynku brakuje odpowiednich materiałów uzupełniających do nauczania treści międzykulturowych (Mihułka, 2010: 359), np. podręczniki do nauki języka niemieckiego zajmują się kulturą jedynie powierzchownie, 
a nauka pozytywnych postaw wobec odmienności kulturowej traktowana jest marginalnie (Mihułka, 2012: 343). Analiza podręczników do nauki języka hiszpańskiego przeprowadzona przez Spychałę (2012: 104) pokazała z kolei, że żaden z nich nie rozwija kompetencji międzykulturowej w zadowalający sposób, zwłaszcza jeśli chodzi o elementy negocjacji z innymi kulturami. Podobną opinię wyraża Chłopek (2009: 65), która nie odnotowała wystarczającej liczby odniesień międzykulturowych w analizowanych podręcznikach do nauki języka niemieckiego.

Innego zdania są osoby analizujące podręczniki do nauki języka angielskiego (Aleksandrowicz-Pędich, 2007; Róg, 2012), których zdaniem liczba i jakość ćwiczeń związanych z kwestiami kulturowymi sprzyjają rozwijaniu międzykulturowej kompetencji komunikacyjnej. Jednakże Rogozińska (2012) wskazuje na problem stronniczości części podręczników, w których kultury inne niż zachodnie bywają prezentowane w sposób subiektywny i negatywny, w przeciwieństwie do krajów anglojęzycznych, przedstawianych w bardzo dobrym świetle. Przykładowo w jednym z podręczników pojawia się rodzina Clavy, która podkreśla pozytywne zmiany po przeprowadzce z Grecji do Kanady, podczas gdy Brytyjczycy, państwo White, podkreślają problemy finansowe i językowe, odkąd przeprowadzili się do Grecji (Rogozińska, 2012: 94).

Analizy materiałów dydaktycznych pokazały również wzrost elementów humorystycznych w nowych podręcznikach do nauki języka polskiego jako obcego, co zdaniem Brzozowskiej (2010: 298) wpływa, choć nadal w niewystarczający sposób, na rozwój międzykulturowej kompetencji humorystycznej. Zdaniem Mackiewicza (2010: 144) podręczniki do nauki języka niemieckiego są oparte o podejście interkulturowe w różnym stopniu. Część z nich zawiera ćwiczenia rozwijające kompetencję międzykulturową, a część wymaga od nauczyciela wysiłku i wrażliwości interkulturowej w przygotowaniu własnych materiałów dydaktycznych. Analiza podręczników do nauki języka hiszpańskiego (Spychała 2007: 272) pokazała, że bywają one bogate w treści kulturowe, choć sposób ich wykorzystania niekoniecznie wspiera edukację międzykulturową. Ponadto zwraca się uwagę (Chłopek 2009: 64), że rzadziej wykorzystywane materiały dydaktyczne, takie jak gazety, programy telewizyjne i radiowe, reklamy itd., mają większy potencjał rozwijania kompetencji międzykulturowej niż podręczniki.

\section{Nowe technologie w nauczaniu IKK}

Zdaniem części badaczy wykorzystanie zdobyczy technologicznych może w znacznym stopniu rekompensować brak możliwości bezpośredniego kontaktu z innymi kulturami. Interakcja za pośrednictwem komputera, nauczanie na odległość lub internetowe projekty wykonywane indywidualnie lub grupowo we współpracy z reprezentantami innych kultur pozwalają na komunikację głosową, tekstową lub 
wizualną, która przybliża do Innego bardziej niż symulacje i odgrywanie ról w klasach monokulturowych (Dryjańska i Ducourtioux, 2012; Gajek, 2012; Wach, 2013; Wach, 2015). Wilczyńska (2013: 182) podkreśla ponadto, że komunikacja interkulturowa $w$ dobie technologii informacyjnych nie może być rozumiana wyłącznie jako bezpośredni kontakt z przedstawicielami obcych kultur, bowiem naszą codziennością jest łatwy dostęp do zagranicznej prasy, telewizji, blogów, for, filmów i obrazów. Zauważa się również, że dodatkowym zyskiem wykorzystania technologii informacyjnych będzie rozwój kompetencji medialnych i technicznych (Gajek, 2012; Wilczyńska, 2013).

Kontakty interkulturowe on-line mogą być szczególnie popularne wśród nastolatków, którzy bardzo intensywnie wykorzystują Internet jako formę spędzania wolnego czasu (Wach, 2013: 378). Okazuje się, że dużą część z ich komunikacji on-line stanowi komunikacja z obcymi kulturami w języku angielskim, zarówno z osobami poznanymi w środowisku naturalnym, jak i wirtualnym. Zdaniem przywołanej badaczki (tamże: 378-379) otwartość uczniów na kontakty międzykulturowe w sieci internetowej stanowi obiecujący potencjał dla nauczycieli, należy jednak pamiętać, że aby tego typu kontakty były istotnie ubogacające, potrzebne jest wsparcie ze strony pedagogów, którzy powinni uczniów na takie kontakty przygotować. Podobne wnioski przynosi analiza komunikacji internetowej studentów polskich i rumuńskich - przyszłych nauczycieli języka angielskiego. Choć nie zastępuje ona naturalnej komunikacji, stanowi istotny krok w kierunku rozwoju kompetencji międzykulturowej, a jej efektywność powinna być wsparta treningiem interkulturowym w klasie (Wach, 2015: 369-370).

Inne podejście proponuje Wilczyńska (2013), która sugeruje wykorzystanie źródeł internetowych do analizy artykułów prasowych, a w szczególności do tropienia różnych sposobów opisywania i komentowania skandali obyczajowych lub afer. W ten sposób postuluje się odejście od podejścia porównawczego na rzecz zachęcania zaawansowanych uczniów języka obcego do rozwinięcia świadomości kulturowej poprzez analizę mediów (warto jednak zapoznać się z badaniami Szczurek-Boruty [2013], która z kolei zaobserwowała dużą przydatność podejścia porównawczego). Taka analiza z jednej strony zmusza ucznia do zrewidowania swoich poglądów na konkretne kwestie kulturowe, a z drugiej może być przyczynkiem do szerszego spojrzenia na kwestie poboczne. Obserwacje praktyk dyskursywnych obcej kultury (w tym również komentarzy internautów) stanowią zarówno trening interkulturowy, jak i ćwiczenie tzw. kompetencji medialnej (Wilczyńska, 2013: 193). 


\section{Dzieci a dorośli i rozwój kompetencji międzykulturowej}

W badaniach dotyczących stanu i możliwości rozwoju kompetencji międzykulturowej u najmłodszych uczniów języków obcych wykazano, że dzieci w większości wykazują świadomość językową i potrafią określić swój stosunek emocjonalny do nich (np. do języka kaszubskiego jako języka regionu) oraz porównać języki ze względu na stopień trudności w ich opanowywaniu (Andrzejewska, 2010: 194). Co charakterystyczne dla sytuacji społecznej w Polsce, języki i kultury często kojarzą się dzieciom bardziej z emigracją zarobkową rodziców niż z doświadczeniami wyniesionymi z lekcji języków obcych w szkole. Zdaniem Siek-Piskozub (2009: 11) dzieci coraz częściej stają się świadkami komunikacji interkulturowej, przez co wzrasta ich świadomość kulturowa i językowa. Obserwuje się, że dzieci są bardziej otwarte na inność kulturową niż dorośli, ponieważ nie wykształciły jeszcze schematów myślowych, są ciekawe świata i pozbawione uprzedzeń. Kompetencja międzykulturowa może być kształcona w dziecku już od momentu narodzin, a wpływ na szybkość i jakość takiego rozwoju będą miały czynniki wewnętrzne i zewnętrzne. Do tych pierwszych Jaroszewska (2009: 167) zalicza zdolność uczenia się, inteligencję i osobowość, a do drugich - status ekonomiczny rodziny, jej potencjalnie wielokulturowy charakter, styl wychowania, wzorce osobowe i doświadczenia kontaktu z innymi kulturami.

Już w przypadku najmłodszych uczniów podkreśla się znaczenie treningu międzykulturowego $\mathrm{w}$ rozwijaniu kompetencji międzykulturowej. W dwujęzycznej szkole podstawowej odnotowano (Szczurek-Boruta, 2013: 162) działania nauczycieli, którzy odnieśli sukces w zakresie kształtowania kompetencji międzykulturowej uczniów. Uczniowie analizowali m.in. zachowania charakterystyczne dla przedstawicieli kultury krajów anglojęzycznych i porównywali je do kultury polskiej. Podobne podejście porównawcze stosowano w przypadku analizy użycia języka w różnych kontekstach sytuacyjnych. Nauczyciele kształtowali ponadto u uczniów gotowość do nawiązywania kontaktów i szacunek dla różnych punktów widzenia. W przypadku treningu międzykulturowego dzieci pomocne okazały się również metody projektów, dramy, bajkoterapii i zajęć relaksacyjnych. Pomogły one dzieciom oswoić się z obcymi sytuacjami i nabrać „odporności emocjonalnej na frustracje i niepowodzenia związane z życiem" (Szczurek-Boruta, 2013: 165).

Słaba znajomość kultury rodzimej i docelowej stanowi istotną trudność dla nauczycieli pracujących w przedszkolach dwujęzycznych. Bielicka (2013: 261) podkreśla, że nauczyciele pracujący metodą immersji często nie radzą sobie w sytuacjach nacechowanych kulturowo, np. gdy trzeba pocieszyć emocjonalnie rozchwiane trzyletnie dziecko. Klasyczne tematy kulturoznawcze omawiane w trakcie kursów na filologiach często okazują się niewystarczające do 
pracy w placówkach immersyjnych na poziomie przedszkolnym i wczesnoszkolnym. Ponadto zarówno studia przygotowujące do nauczania języków obcych w przedszkolach, jak i zawartość programów nauczania w stopniu znikomym uwzględniają edukację interkulturową (Róg, 2015).

Specjalnie do nauczycieli najmłodszych uczniów skierowany był projekt COALA (Lewicki i in., 2006), który miał na celu włączenie edukacji międzykulturowej do programów nauczania na etapie przedszkolnym i wczesnoszkolnym. W trwających trzy lata kursach COALA organizowanych w krajach Unii Europejskiej brały udział osoby przygotowujące się do zawodu i czynni nauczyciele języków obcych. Wśród poruszanych zagadnień były elementy wiedzy o geografii, polityce i realioznawstwie krajów anglo- i niemieckojęzycznych, zagadnienia komunikacji międzykulturowej, rozwiązywanie problemów związanych z wielojęzycznością i wielokulturowością w klasie językowej oraz praktyczne porady nt. włączania podejścia interkulturowego do nauki języków. W wyniku tych działań poglądy kursantów nt. komunikacji międzykulturowej uległy zmianie. Postrzeganie kompetencji międzykulturowej jako procesu zdobywania wiedzy ustąpiło miejsca postrzeganiu jej przede wszystkim jako zdolności wzajemnego oddziaływania w kontekście interakcji między ludźmi z różnych kultur i samodzielnego zdobywania tej wiedzy (Lewicki i in., 2006: 102).

Również polscy seniorzy coraz częściej przejawiają zainteresowanie obcą kulturą i chęć konfrontacji z nią dzięki znajomości języków obcych. Jaroszewska (2013) opisuje projekt, który był nakierunkowany na popularyzację mobilności wśród osób dorosłych powyżej 50. roku życia w ramach kursów języków obcych o charakterze wyjazdowym, który odbywał się w warunkach międzykulturowości. Zdaniem badaczki (2013: 285) seniorzy w Polsce wykazują dużą świadomość pluralizmu języków i kultur oraz przejawiają zainteresowanie i pozytywne postawy względem tzw. inności kulturowej. Dlatego rozwijanie kompetencji międzykulturowej osób dorosłych/seniorów nie powinno się ograniczać wyłącznie do kontaktu z obcą kulturą poprzez osobę nauczyciela. Proces nauczania powinien zawierać możliwie dużo elementów interakcji z rodzimymi użytkownikami danego języka - jeśli nie poprzez wyjazdy edukacyjne, to poprzez nowe technologie i pomoce naukowe lub inscenizacje, które pomagają uzyskać warunki zbliżone do naturalnych (tamże: 288). Badanie Jaroszewskiej wykazało także, że dla seniorów bardziej od wieku nauczyciela języka obcego ważne są jego kompetencje językowe i przede wszystkim jego doświadczenie zdobyte na gruncie kontaktów międzykulturowych (tamże).

Osoby dorosłe uczące się języka obcego mogą jednak wymagać innego podejścia do rozwijania kompetencji międzykulturowej. O ile młodzież wykazuje relatywnie większą łatwość w asymilowaniu się z nową kulturą, o tyle uczniowie dorośli mogą wykazywać w tej kwestii problemy. Zdaniem Król (2011: 
104) rozwijanie kompetencji międzykulturowej jest właśnie szczególnie istotne w edukacji językowej dorosłych, którzy mają już wykształcone pewne sposoby patrzenia na świat, a zatem mogą przyjmować, że ich utarte modele zachowań sprawdzą się w każdej sytuacji komunikacyjnej. Takie błędne założenie zdaniem przywołanej autorki prowadzi do wielu nieporozumień i kłopotliwych sytuacji na tle kulturowym.

Praktyczny wymiar rozwijania kompetencji międzykulturowej w pracy z uczniami dorosłymi wiąże się m.in. z wykorzystaniem ćwiczeń tłumaczeniowych. Przywołując argumenty Schefflera (2007), Wójcik (2010: 168) zwraca uwagę, że ćwiczenia te nie mogą stanowić podstawy kursu ani być nadużywane, ale z racji tego, że osoby dorosłe przyswajają język obcy inaczej niż dzieci, rozumują analitycznie i świadomie formułują hipotezy, mogą stanowić narzędzie wspierające rozwijanie postaw otwartości, np. poprzez analizę zapożyczeń.

\section{Wnioski}

W powyższym artykule przedstawiono główne nurty polskich badań nad kompetencją międzykulturową w glottodydaktyce. Analizie poddano ponad sto publikacji, wśród których znalazły się zarówno rozważania na poziomie teoretycznym, jak i badania empiryczne. Analiza zebranych dokumentów pozwala na wyciągnięcie następujących wniosków:

1) głównymi technikami zbierania danych są

a) w przypadku oceny stanu kompetencji międzykulturowej nauczycieli i uczniów: wywiady z nauczycielami i uczniami, obserwacje lekcji i ankiety samooceny;

b) w przypadku oceny materiałów dydaktycznych: analizy programów nauczania i podręczników. Z pewnością cennych informacji dostarczyłyby analizy scenariuszy lekcji;

2) kształcenie interkulturowe, mimo wielu postulatów akademickich, odgrywa w polskiej szkole rolę marginalną;

3) istotną rolę w kształceniu przyszłych nauczycieli języków obcych powinny odgrywać treningi interkulturowe, przy czym wyzwaniem dla prowadzących jest określenie, jakie mają być ich efekty;

4) praktykujący nauczyciele języków obcych znają zagadnienie międzykulturowości, ale brak im umiejętności prowadzenia treningów interkulturowych na lekcjach, mimo że w polskiej glottodydaktyce wypracowano szeroki inwentarz technik wspierających rozwój kompetencji międzykulturowej (m.in. analiza zachowań codziennych, analiza procesów komunikacji interkulturowej, krytyczne spojrzenie na stereotypy, 
praca z filmem, muzyką, tekstem pisanym, materiałami autentycznymi, dyskusje, drama, projekty etnograficzne itd.);

5) podręczniki dostępne na rynku w różnym stopniu umożliwiają rozwój kompetencji międzykulturowej; badania wskazują, że najlepiej tę funkcję pełnią podręczniki do nauki języka angielskiego;

6) niedoceniona pozostaje wartość materiałów autentycznych, których odpowiednie wykorzystanie mogłoby rekompensować braki odpowiednich treści interkulturowych w materiałach dydaktycznych;

7) cennym doświadczeniem, coraz szerzej dostępnym polskim uczniom i studentom, jest udział w wyjazdach i wymianach zagranicznych;

8) brak bezpośredniego dostępu do przedstawicieli obcych kultur może być zrekompensowany przez wykorzystanie technologii: internetowe projekty, wymiany on-line, nauczanie na odległość; nową rolą nauczyciela jest przygotowanie uczniów do tego typu komunikacji, aby stała się ona w istocie wzbogacającą ich kompetencję międzykulturową;

9) kontakt z obcą kulturą nie oznacza wyłącznie kontaktu z drugim człowiekiem; wiele na temat wartości wyznawanych przez daną kulturę można się dowiedzieć z analizy materiałów autentycznych;

10) rozwijanie kompetencji międzykulturowej można rozpocząć od najmłodszych lat, jednakże zarówno programy nauczania, jak i kursy przygotowujące nauczycieli wychowania przedszkolnego w znikomym stopniu poruszają zagadnienie międzykulturowości;

11) podejście interkulturowe w edukacji językowej seniorów wymaga refleksji na temat przyzwyczajeń osób starszych oraz wzięcia pod uwagę innych sposobów przyswajania wiedzy i umiejętności.

Jak wykazano powyżej, najczęstszymi badaniami są te prowadzone wśród nauczycieli języków obcych, a najrzadszymi - te poświęcone edukacji interkulturowej najmłodszych i najstarszych uczących się języków. Z racji rosnącej mobilności edukacyjnej uczniów, studentów i kadry pedagogicznej coraz więcej badaczy zajmuje się możliwością wspierania rozwoju kompetencji międzykulturowej tych osób w ramach lekcji języka obcego przed ich przedłużonym kontaktem z obcą kulturą oraz po nim. Jeszcze inną ścieżką badawczą stają się lekcje języka polskiego jako obcego dla wielokulturowych grup uczniów w polskich instytucjach.

Niezależnie od tego, w którym kierunku potoczą się badania nad międzykulturowością w polskiej glottodydaktyce, nieunikniona i konieczna staje się potrzeba informowania glottodydaktyki przez inne dyscypliny badawcze związane z kontaktami międzykulturowymi. Badania te pozwalają coraz lepiej zrozumieć ludzkie zachowania, a interdyscyplinarne podejście do badań nad interkulturowością może prowadzić do bardziej odpowiednich aplikacji glottodydaktycznych. 


\section{BIBLIOGRAFIA}

Adamczak-Krysztofowicz, S. 2006. „Miejsce i rola nauczania interkulturowego na studiach germanistycznych i w kolegiach nauczycielskich w Polsce. Prezentacja wybranych wyników badań empirycznych". Neofilolog, 26: 27-34.

Adamczak-Krysztofowicz, S. 2012: „Rola podróży studyjnych w procesie świadomej refleksji i relatywizacji stereotypów: projekt polsko-niemiecki”. (w) Interkulturowość, kreatywność, refleksyjność w dydaktyce języków obcych. (red. E. Wąsikiewicz-Firlej, A. Szczepaniak-Kozak i H. Lankiewicz). Piła: Państowa Wyższa Szkoła Zawodowa w Pile, str. 85-96.

Aleksandrowicz-Pędich, L. 2005a. Międzykulturowość na lekcjach języków obcych. Białystok: Wydawnictwo Uniwersytetu w Białymstoku.

Aleksandrowicz-Pędich, L. 2005b: „Postawy nauczycieli języków obcych w Europie wobec rozwijania kompetencji międzykulturowej”. (w) Język trzeciego tysiq̨clecia III. Język polski i języki obce - kontakty, kultura, dydaktyka. (red. M. Dąbrowska). Kraków: Tertium, str. 347-354.

Aleksandrowicz-Pędich, L. 2007: „Interkulturowość w kształceniu językowym w Polsce i innych krajach europejskich". (w) Nauczanie języków obcych - Polska a Europa. (red. H. Komorowska). Warszawa: Wydawnictwo SWPS Academica, str. 39-56.

Andrzejewska, E. 2010: „Język kaszubski i języki obce - świadomość językowa i (wielo)kulturowa uczniów pomorskich szkół podstawowych". (w) Kompetencja interkulturowa w teorii i praktyce edukacyjnej. (red. M. Mackiewicz). Poznań: Wydawnictwo Wyższej Szkoły Bankowej, str. 185-198.

Balcerkiewicz, M. i B. Kułaczkowska. 2010: „Spotkania na granicy różnych światów poznanie siebie i innych. Praca z filmem na zajęciach języka obcego w ramach rozwoju kompetencji interkulturowej". (w) Kompetencja interkulturowa w teorii i praktyce edukacyjnej. (red. M. Mackiewicz). Poznań: Wydawnictwo Wyższej Szkoły Bankowej, str. 175-184.

Bandura, E. 2007. Nauczyciel jako mediator interkulturowy. Kraków: Tertium.

Białek, M. 2009. Kształcenie międzykulturowe w edukacji językowej. Wrocław: Oficyna Wydawnicza ATUT - Wrocławskie Wydawnictwo Oświatowe.

Bielicka, M. 2013. „Kompetencje nauczyciela języka obcego w przedszkolu immersyjnym. Przygotowanie studentów kierunków neofilologicznych do wykonywania zawodu nauczyciela w przedszkolu dwujęzycznym". Neofilolog, 40(2): 251-264.

Brzozowska, D. 2010: „Humor w podręcznikach do nauczania języka polskiego jako obcego". (w) Słowo w dialogu międzykulturowym. (red. W. Chłopicki i M. Jodłowiec). Kraków: Tertium, str. 291-300.

Byram, M. 1997. Teaching and assessing intercultural communicative competence. Clevedon: Multilingual Matters.

Chłopek, Z. 2009a. „Nauczanie kultury na lekcji języka obcego w Polsce: wyniki badań kwestionariuszowych". Języki Obce w Szkole, 1: 61-68.

Chłopek, Z. 2009b: „Kształcenie nauczycieli języków trzecich lub kolejnych”. (w) Nauczyciel języków obcych dziś i jutro. (red. M. Pawlak, A. Mystkowska-Wiertelak i 
A. Pietrzykowska). Poznań - Kalisz: Wydział Pedagogiczno-Artystyczny UAM w Kaliszu, Uniwersytet im. Adama Mickiewicza w Poznaniu, str. 167-177.

Chudak, S. 2013. „Kompetencja medialna uczniów i nauczycieli języków obcych jako czynnik wpływający na poziom ich kompetencji interkulturowej". Neofilolog, 40(2): 219-236.

Chylewska-Tölle, A. 2010: „O edukacji międzykulturowej inaczej. Możliwość jej zastosowania na zajęciach z literatury niemieckiej". (w) Kompetencja interkulturowa w teorii i praktyce edukacyjnej. (red. M. Mackiewicz). Poznań: Wydawnictwo Wyższej Szkoły Bankowej, str. 151-162.

Dmowska, B. 2005. Podstawa programowa kształcenia ogólnego. Projekt. Warszawa: Instytut Spraw Publicznych.

Dryjańska, A. i S. Ducourtioux. 2012. „Zajęcia na odległość w nauczaniu treści kulturowych". Języki Obce w Szkole, 3: 42-45.

Gajek, E. 2012. „Komunikacja językowa i międzykulturowa uczniów w projektach eTwinning". Języki Obce w Szkole, 3: 37-41.

Grabowska, A. 2013. „Kształtowanie postawy otwartości interkulturowej nauczycieli języków obcych w świetle zaleceń Unii Europejskiej i na przykładzie Asystentury Comeniusa". Neofilolog, 40(2): 237-250.

Jaroszewska, A. 2009: „Świadomość wielokulturowa dziecka w strukturze kompetencji międzykulturowej - od teorii do praktyki". (w) Wczesnoszkolne nauczanie języków obcych. Zarys teorii i praktyki. (red. D. Sikora-Banasik). Warszawa: Wydawnictwa CODN, str. 160-180.

Jaroszewska, A. 2013. Nauczanie języków obcych seniorów w Polsce. Analiza potrzeb i możliwości w aspekcie międzykulturowym. Kraków: Impuls.

Jodłowiec, M. 2005: „Techniki ludyczne w kształtowaniu świadomości różnic międzykulturowych". (w) Kompetencja interkulturowa w teorii i praktyce edukacyjnej. (red. M. Mackiewicz). Poznań: Wydawnictwo Wyższej Szkoły Bankowej, str. 269-278.

Jodłowiec, M. i M. Urban. 2010: „Kompetencja pragmatyczna a poziom zaawansowania w języku angielskim wśród Polaków uczących się języka angielskiego”. (w) Słowo w dialogu międzykulturowym. (red. Chłopicki, W. i M. Jodłowiec). Kraków: Tertium, str. 311-322.

Kaiser, W. i Ł. Kuciński. 2002. Program nauczania - alles klar. Warszawa: WSiP.

Karolczuk, M. 2014. „Rola refleksji w przygotowaniu ucznia do komunikacji międzykulturowej na lekcji języka rosyjskiego". Neofilolog, 42(2): 215-226.

Karpińska-Musiał, B. 2006: „Intercultural speaker jako odpowiedź na współczesne wyzwania globalnego społeczeństwa wiedzy. Analiza procesu nabywania kompetencji międzykulturowej przez ucznia i nauczyciela języków obcych". (w) Komunikacja językowa w społeczeństwie informacyjnym. Nowe wyzwania dla dydaktyki języków obcych (red. J. Krieger-Knieja i U. Paprocka-Piotrowska). Lublin: Towarzystwo Naukowe KUL Jana Pawła II, str. 261-272.

Kaszyński, M. 2009. Treść podręczników a rozwój kompetencji interkulturowej w nauczaniu języków obcych osób dorosłych. Nieopublikowana praca doktorska. Poznań, UAM. 
Krawiec, M. 2010: „Stereotypy kulturowe w kontekście nauczania języka angielskiego”. (w) Heteronomie glottodydaktyki. Księga jubileuszowa z okazji sześćdziesięciolecia urodzin prof. dr hab. Teresy Siek-Piskozub. (red. Z. Wąsik i A. Wach). Poznań: Instytut Filologii Angielskiej, str. 139-152.

Król, W. 2011. „Język a kultura - rozwijanie świadomości interkulturowej u uczniów dorosłych: optymalne techniki dydaktyczne". Neofilolog, 37: 101-107.

Kuriata, J. 2002. Kompetencja interkulturowa w kształceniu nauczycieli języków obcych na przykładzie języka francuskiego. Nieopublikowana praca doktorska. Poznań: Uniwersytet im. Adama Mickiewicza.

Kurtyka, A. 2005: „Rozwijanie kompetencji międzykulturowej nauczycieli języków obcych". (w) Kompetencja interkulturowa w teorii i praktyce edukacyjnej. (red. M. Mackiewicz). Poznań: Wydawnictwo Wyższej Szkoły Bankowej, str. 83-96.

Lewicki, R., Białek, M. i A. Gackowska. 2006. Kompetencja międzykulturowa w kształceniu nauczycieli języków obcych na potrzeby edukacji wczesnoszkolnej. Teoria i praktyka. Wrocław: Oficyna Wydawnicza ATUT.

Mackiewicz, M. 2006. „Orientacja (inter)kulturowa zajęć języka niemieckiego na poziomie ponadgimnazjalnym - fakty i mity". Neofilolog, 28: 33-39.

Mackiewicz, M. 2009: „Nauczyciel języka obcego jako kulturoznawca i mediator interkulturowy. Kilka refleksji i postulatów z perspektywy germanistycznej". (w) Nauczyciel języków obcych dziś i jutro. (red M. Pawlak, A. Mystkowska-Wiertelak i A. Pietrzykowska). Poznań - Kalisz: Wydział Pedagogiczno-Artystyczny UAM w Kaliszu, Uniwersytet im. Adama Mickiewicza w Poznaniu, str. 71-82.

Mackiewicz, M. 2010: „Standardy kulturowe a dydaktyka języków obcych”. (w) Kompetencja interkulturowa w teorii i praktyce edukacyjnej. (red. M. Mackiewicz). Poznań: Wydawnictwo Wyższej Szkoły Bankowej, str. 137-150.

Matlakiewicz A. i H. Solarczyk-Szewc. (2005) Dorośli uczq się inaczej. Andragogiczne podstawy kształcenia ustawicznego. Toruń: Wyd. Centrum Kształcenia Ustawicznego.

Mihułka, K. 2010: „Edukacja międzykulturowa - założenia, cele, zadania”. (w) Słowo w dialogu międzykulturowym. (red. W. Chłopicki i M. Jodłowiec). Kraków: Tertium, str. 355-364.

Mihułka, K. 2012. Rozwój kompetencji interkulturowej w warunkach szkolnych - mity a polska rzeczywistość na przykładzie języka niemieckiego jako L3. Rzeszów: Wydawnictwo Uniwersytetu Rzeszowskiego.

Mihułka, K. 2014. „Nie lubię Niemców, bo nie - o autorefleksji w postrzeganiu innych”. Neofilolog, 42(1): 63-77.

Niżegorodcew, A. 2015: „Local cultures in English: Intercultural communication in an international educational context". (w) Issues in teaching, learning and testing speaking in a second language. (red. M. Pawlak i E. Waniek-Klimczak). Berlin Heidelberg: Springer-Verlag, str. 19-28.

Owczarek, D. 2010: „Preparing teacher trainees for multicultural classrooms - interviews with Erasmus and Comenius students”. (w) Coping with diversity. (red. H. Komorowska i L. Aleksandrowicz-Pędich). Warszawa: Wydawnictwo SWPS, str. 303-313.

Paprocka-Piotrowska, U. 2007: „Stereotyp w dialogu interkulturowym - wprowadzenie do warsztatu". (w) Dydaktyka języków obcych na poczq̨tku XXI wieku (red. 
M. Jodłowiec i A. Niżegorodcew). Kraków: Wydawnictwo Uniwersytetu Jagiellońskiego, str. 287-292.

Piórkowska, A. 2005. Are English course-book stereotype-free. A case study of the Project series. Nieopublikowana praca magisterska. Poznań: Uniwersytet im. Adama Mickiewicza.

Podkowińska-Lisowicz, M. 2004. Program nauczania języka niemieckiego dla gimnazjum. Warszawa: Langenscheidt.

Pytlarz, A. 2005: „Stereotypy a kształcenie interkulturowe - nowy profil nauczyciela języka obcego". (w) Nauka języków obcych w dobie integracji europejskiej (red. K. Karpińska-Szaj). Łask: Oficyna Wydawnicza LEKSEM, str. 211-218.

Rogozińska, E. 2012: „Biased cultural content of ELT textbooks. Critical analytic study of ELT textbooks used in Polish schools". (w) Informed teaching - premises of modern foreign language pedagogy. (red. H. Lankiewicz i E. WąsikiewiczFirlej). Piła: Państwowa Wyższa Szkoła Zawodowa w Pile, str. 87-98.

Romanowski, P. 2011. Developing cross-cultural communication competence in foreign language classes (on the example of English). Nieopublikowana praca doktorska. Kraków: Uniwersytet Jagielloński.

Róg, T. 2012: „Perspectives on intercultural communicative competence in a secondary-school EFL course book". (w) Wielowymiarowość i perspektywy nauki za progiem XXI wieku. Tom IV. (red. E. Widawska i K. Kowal). Częstochowa: Wydawnictwo AJD, str. 227-239.

Róg, T. 2013. Intercultural speakers and study abroad programmes. The case of Erasmus students. Saarbrucken: Lambert Academic Publishing

Róg, T. 2014a. „Dydaktyka języków obcych wobec rosnącej mobilności studentów”. Języki Obce w Szkole, 1: 7-13.

Róg, T. 2014b: „Intercultural training in contemporary education”. (w) Cross-curricular dimensions of language learning and teaching (red. M. Krawiec). Newcastle upon Tyne: Cambridge Scholars Publishing, str. 201-218.

Róg, T. 2015. „Intercultural education at a pre-school level in the context of Polish kindergarten curriculum changes". The Journal of Linguistic and Intercultural Education, 8: 179-201.

Siek-Piskozub, T. 2009: „Nauczanie języków obcych dzieci w wieku wczesnoszkolnym wyzwania i problemy". (w) Wczesnoszkolne nauczanie języków obcych. Zarys teorii i praktyki. (red. D. Sikora-Banasik). Warszawa: Wydawnictwa CODN, str. 9-19.

Siek-Piskozub, T. 2012a. „Międzykulturowa kompetencja komunikacyjna wyzwaniem dla glottodydaktyki". Lingwistyka Stosowana, 5: 95-108.

Siek-Piskozub, T. 2012b: „Use of simulations for the development of intercultural communicative competence in EFL teacher education". (w) International Symposium on Language and Communication: research, trends and challenges. Proceedings book. Izmir: Izmir University, str. 2277-2289.

Siek-Piskozub, T. 2013: „Enhancing autonomy in the context of an ICC development seminar". (w) Exploring the microcosm and macrocosm of language teaching and learning. (red. M. Jodłowiec i E. Mańczak-Wohlfeld). Kraków: Wydawnictwo Uniwersytetu Jagiellońskiego, str. 217-228. 
Siek-Piskozub, T. 2014a: „Educating FL Teachers for the Role of Intercultural Mediators Challenges and Options". (w) Intercultural issues in the era of globalisation. (red. P. Romanowski). Warszawa: Wydawnictwo Naukowe IKSiL UW, str. 191-199.

Siek-Piskozub, T. 2014b: „Intercultural communicative competence: a natural need”. (w) Cross-curricular dimensions of language learning and teaching. (red. M. Krawiec). Newcastle upon Tyne: Cambridge Scholars Publishing, str. 191-200.

Sobek, A. 2012: „Nauczanie piątej umiejętności w działaniu: projekty badawcze studentów w KJO UAM-u i Carl von Ossietzky Universität w Oldenburgu". (w) Interkulturowość, kreatywność, refleksyjność w dydaktyce języków obcych. (red. E. Wąsikiewicz-Firlej, A. Szczepaniak-Kozak i H. Lankiewicz). Piła: Państwowa Wyższa Szkoła Zawodowa w Pile, str. 109-122.

Sobkowiak, P. 2012. „Dialog interkulturowy na lekcji języka angielskiego w kontekście polskim”. Neofilolog, 38(1): 107-128.

Spychała, M. 2007: „Model kompetencji interkulturowej a kryteria oceny materiałów nauczania na przykładzie podręczników do nauki języka hiszpańskiego". (w) Dydaktyka języków obcych na poczq̨tku XXI wieku. (red. M. Jodłowiec i A. Niżegorodcew). Kraków: Wydawnictwo Uniwersytetu Jagiellońskiego, str. 267-274.

Stankiewicz K. i A. Żurek. 2010: „Treści interkulturowe w programach do nauczania języka polskiego jako obcego". (w) Słowo w dialogu międzykulturowym. (red. W. Chłopicki i M. Jodłowiec). Kraków: Tertium, str. 375-383.

Stankiewicz K. i A. Żurek. 2011. „Międzykulturowe uczenie się na kursie języka polskiego jako obcego". Język. Komunikacja. Informacja, 6: 187-194.

Strzałka, A. 2005: „Rozwijanie pedagogicznej świadomości interkulturowej przyszłych i obecnych nauczycieli języka angielskiego". (w) Język polski i języki obce - kontakty, kultura, dydaktyka (red. M. Dąbrowska). Kraków: Tertium, str. 371-379.

Szczurek-Boruta, A. 2013. „Nauczyciele i kształtowanie kompetencji międzykulturowej uczniów". Pogranicze. Studia Społeczne, XXI: 155-169.

Torenc, M. 2007. Nauczanie międzykulturowe -implikacje glottodydaktyczne. Wrocław: Oficyna Wydawnicza ATUT.

Utri, R. 2007. Interkulturalität und Fremdsprachenlernen in Österreich, Deutschland und Polen vor dem Hintergrund der Sprachenpolitik der Europäischen Union. Nieopublikowana praca doktorska. Warszawa: Uniwersytet Warszawski.

Wach, A. 2013. „Polish teenage students' willingness to engage in on-line intercultural interactions". Intercultural Education, 24: 374-381.

Wach, A. 2015: „Advanced Learners' Intercultural Experience Through Computer-Enhanced Technology: A Study of Polish and Romanian Students". (w) New Media and Perennial Problems in Foreign Language Learning and Teaching. (red. L. Piasecka i in.). Cham - Heidelberg - New York - Dordrecht - London: Springer, str. 21-38.

Wałowski, P. 2012: „Literatura piękna jako medium socjohistorycznej kompetencji interkulturowej w nauczaniu języka niemieckiego. Uwagi i propozycje". (w) Interkulturowość, Kreatywność, Refleksyjność w Dydaktyce Języków Obcych. (red. E. Wąsikiewicz-Firlej, A. Szczepaniak-Kozak i H. Lankiewicz), Piła: Państwowa Wyższa Szkoła Zawodowa w Pile, str. 13-22. 
Wilczyńska, W. 2002: „Badania interkulturowe w praktyce dydaktycznej”. (w) European Year of Languages. (red. T. Siek-Piskozub). Poznań: Wydawnictwo Naukowe UAM, str. 18-24.

Wilczyńska, W. 2013: „Integrating intercultural (IC) and media competence: The DSK affair from a cross-cultural perspective". (w) Exploring the microcosm and macrocosm of language teaching and learning. (red. M. Jodłowiec i E. MańczakWohlfeld). Kraków: Wydawnictwo Uniwersytetu Jagiellońskiego, str. 181- 196.

Wilczyńska, W. i A. Michońska-Stadnik. 2010. Metodologia badań w glottodydaktyce. Kraków: Avalon.

Wójcik, D. 2010: „Rozwijanie kompetencji interkulturowej na lekcji języka niemieckiego. Analiza wybranych przykładów z podręcznika Partnersprache". (w) Kompetencja interkulturowa w teorii i praktyce edukacyjnej. (red. M. Mackiewicz). Poznań: Wydawnictwo Wyższej Szkoły Bankowej, str. 163-174.

Zagdańska-Dudek, K. 2012: „Kultura w nauczaniu języka francuskiego: wyniki ankiety przeprowadzonej wśród nauczycieli". (w) Dydaktyka języka obcego w okresie przemian. (red. M. Jodłowiec i A. Tereszkiewicz). Kraków: Tertium, str. 97-106

Zając, J. 2012. „Kompetencje mediacyjne nauczyciela języków obcych w perspektywie interkulturowej". Języki Obce w Szkole, 1: 14-21.

Zawadzka, E. 2004. Nauczyciele języków obcych w dobie przemian. Kraków: Impuls.

Żydek-Bednarczuk, U. 2012. „Kompetencja międzykulturowa w nauczaniu języka polskiego jako obcego". Postscriptum Polonistyczne, 2: 19-30.

Żylińska, M. 2003. „Podejście interkulturowe, czyli o konieczności zmian w nauczaniu języków obcych”. Języki Obce w Szkole, 6: 49-62. 